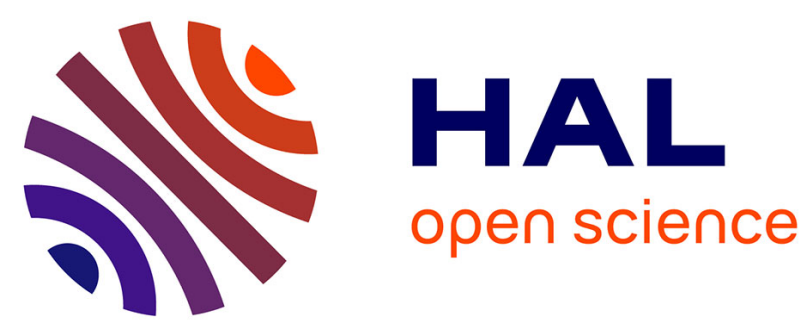

\title{
Synthesis, characterization and thermal behaviour of mixed-ligand complexes of cobalt(III) with dimethylglyoxime and some amino acids.
}

\author{
A. Adkhis, O. Benali-Baitich, Mustayeen A. Khan, G. Bouet.
}

\section{To cite this version:}

A. Adkhis, O. Benali-Baitich, Mustayeen A. Khan, G. Bouet.. Synthesis, characterization and thermal behaviour of mixed-ligand complexes of cobalt(III) with dimethylglyoxime and some amino acids.. Synthesis and Reactivity in Inorganic and Metal-Organic Chemistry, 2000, 30 (10), pp.1849-1858. 10.1080/00945710009351873 . hal-03208776

\section{HAL Id: hal-03208776 \\ https://univ-angers.hal.science/hal-03208776}

Submitted on 30 Apr 2021

HAL is a multi-disciplinary open access archive for the deposit and dissemination of scientific research documents, whether they are published or not. The documents may come from teaching and research institutions in France or abroad, or from public or private research centers.
L'archive ouverte pluridisciplinaire HAL, est destinée au dépôt et à la diffusion de documents scientifiques de niveau recherche, publiés ou non, émanant des établissements d'enseignement et de recherche français ou étrangers, des laboratoires publics ou privés. 


\title{
SYNTHESIS, CHARACTERIZATION AND THERMAL BEHAVIOUR OF MIXED-LIGAND COMPLEXES OF COBALT(III) WITH DIMETHYLGLYOXIME AND SOME AMINO ACIDS
}

\author{
A. Adkhis ${ }^{a}$, O. Benali-Baitich ${ }^{a}$, M. A. Khan ${ }^{b}$ and G. Bouet ${ }^{b}$ \\ a Laboratoire de Chimie de Coordination, Institut de Chimie, USTHB, BP 32 , El Alia, \\ Bab Ezzouar, Algeria \\ 'Laboratoire de Chimie de Coordination, Faculté de Pharmacie, Université d'Angers, \\ 16 Boulevard Daviers, F- 49100 Angers, France
}

\begin{abstract}
Non-electrolyte complexes of the general formula $\left[\mathrm{Co}(\mathrm{Hdmg})_{2}(\mathrm{HA}) \mathrm{X}\right]$ where $\mathrm{Hdmg}=$ dimethylglyoximato monoanion, $\mathrm{HA}=$ alanine, threonine or histidine and $\mathrm{X}=\mathrm{Cl}, \mathrm{Br}, \mathrm{I}, \mathrm{SCN}$ were synthesized and characterized by elemental analyses, IR, UV-Visible and ${ }^{1} \mathrm{H}$ NMR spectra. The complexes are pseudo-octahedral with two dimethylglyoximato ligands $\mathrm{N}$ bonded to the metal in the equatorial plane, the two axial sites being occupied by one amino acid molecule and one halogen or pseudo halogen anion. The thermal behaviour of these cobalt(III) complexes, determined by thermogravimetry (TG) and differential thermal analysis (DTA), shows that the dimethylglyoximato ligand is thermally more stable than the two other ligands.
\end{abstract}

\section{INTRODUCTION}

Cobalt complexes based on $\alpha, \beta$-dione dioximes as the main ligands and the so called cobaloximes constitute an important class of chemical materials due to their close relationship to vitamin $B_{12}{ }^{1,2}$. Thus, these materials, especially those based on dimethylglyoxime $\left(\mathrm{H}_{2} \mathrm{dmg}\right)$, have been a major focus of systematic studies in past decades, 
primarily so in search of a sound understanding of factors and mechanisms that control the biological activities of vitamin $B_{12}{ }^{3-5}$.

Mixed-ligand complexes of cobalt(III) with dimethylglyoxime as primary ligand, halogens as secondary ligand and various amines as tertiary ligand have been the subject of many structural studies $^{6.8}$. There are no literature references on the use of amino acids as tertiary ligand in such complexes.

In view of the important biological activity of the amino acids some cobaloximes with alanine, threonine and histidine were synthesized and characterized by microanalyses, conductivity, IR. UV-Visible and 'H NMR spectrometry. Based on the result obtained, tentative structures are proposed for the complexes. The thermal behaviour of these complexes, determined by thermogravimetry and differential thermal analysis, was discussed on the light of the structure proposed.

\section{EXPERIMENTAL}

\section{$\underline{\text { Materials }}$}

All chemical reagents and solvents used in the synthesis of complexes were Flake products and used without further purification. The amino acids used were: $\mathrm{L}(+)$ alanine (Ala), $\mathrm{L}(-)$ histidine (His) and L(-) threonine (Thr).

\section{Preparation of Complexes}

All complexes were prepared using the following general method. To a solution of $\mathrm{CoCl}_{2} .6 \mathrm{H}_{2} \mathrm{O}$, (3.57 g, 15 mmoles) in ethanol-water $(50 \%$ by volume) were added dimethylglyoxime ( $3.48 \mathrm{~g}, 30$ mmoles), amino acid ( 15 mmoles) and $\mathrm{NaBr}, \mathrm{NaI}$ or $\mathrm{KSCN}$ (15 mmoles) with constant stirring at room temperature during 2-4 $\mathrm{h}$. In the synthesis of chloro complexes, the $\mathrm{Cl}$ come from $\mathrm{CoCl}_{2}$. After the precipitation of a colored solid, the mixture was kept stirring at room temperature and air was bubbled into the solution for additional 2-4 $\mathrm{h}$ to achieve oxidation. The complexes were isolated by filtration, washed once with absolute $\mathrm{EtOH}$ and three times with diethyl ether and finally dried in air.

\section{Physical Measurements}

The elemental microanalyses were carried out at the Service Central d'Analyse du CNRS (Vernaison, France). Magnetic measurements were made at room temperature by the Gouy method using a Setaram G-70 electrobalance calibrated with Mohr's salt. Conductance values were obtained with a Tacusel $C D-810$ conductimeter at room temperature of $10^{-3} \mathrm{~mol} \cdot \mathrm{L}^{-1}$ 
solutions of the complexes in DMSO. The IR spectra were recorded with a Shimadzu FTIR$9101 \mathrm{M}$ spectrophotometer between 4000 and $400 \mathrm{~cm}^{-1}$ ( $\mathrm{KBr}$ discs). Electronic absorption spectra were recorded with a Shimadzu UV-1601 UV-Visible spectrophotometer in DMSO solutions. The 'H NMR spectra were obtained with a Jeol GSX $270 \mathrm{MSB}(270 \mathrm{MHz})$ spectrophotometer in DMSO- $\mathrm{d}_{6}$ solution of the complexes and the dimethylglyoxime ligand, and in $\mathrm{D}_{2} \mathrm{O}$ solutions of the amino acids ligands using TMS as internal reference (Service Commun de RMN, Université d'Angers).

\section{RESULTS AND DISCUSSION}

The analytical data of the complexes are given in Table I. On the basis of the analytical data, the complexes have the general formula $\left[\mathrm{Co}(\mathrm{Hdmg})_{2}(\mathrm{HA}) \mathrm{X}\right]$ showing that dimethylglyoximato group acts as a monoanion. The molar conductance values of all complexes in DMSO at $10^{-3} \mathrm{~mol} \cdot \mathrm{L}^{-1}$ are in the range $2-50 \Omega^{-1} \cdot \mathrm{cm}^{2} \cdot \mathrm{mol}^{-1}$ and suggest that the complexes are non-electrolytes ${ }^{9}$. Magnetic measurements show that these complexes are diamagnetic and this is due to the presence of cobalt(lli) as central ion .

\section{$\underline{\text { IR Studies }}$}

The main IR bands of both ligands and the complexes are given in Table II. The spectra of the amino acids exhibit the $v\left(\mathrm{NH}_{3}{ }^{\circ}\right)$ band in the $3030-3130 \mathrm{~cm}^{-1}$ range ${ }^{10}$. In alanine, threonine and histidine this band is located at 3080,3030 and $3090 \mathrm{~cm}^{-1}$, respectively. The $\delta\left(\mathrm{NH}_{3}{ }^{+}\right)$ vibration leads to a band in the $1610-1640 \mathrm{~cm}^{-1}$ region. In the complexes, $v\left(\mathrm{NH}_{3}{ }^{+}\right)$is shifted to higher wave numbers. The bands of medium intensity appearing at $1578-1593 \mathrm{~cm}^{-1}$ are due to the asymmetric stretching vibration of the $\mathrm{COO}^{-}$moiety ${ }^{10,11}$. The broad bands which occur in the $1625 \mathrm{~cm}^{-1}$ region may be attributed to the asymmetric vibration of threonine. In the spectra of the complexes the broad bands of medium intensity appearing between 1547 and $1578 \mathrm{~cm}^{-1}$ are assigned to the asymmetric stretching vibration of the $\mathrm{COO}^{-}$group. The $v(C=N)$ band appearing at $1447 \mathrm{~cm}^{-1}$ in dimethylglyoxime is slightly shifted to $1444 \mathrm{~cm}^{-1}$, this suggests that dimethylglyoxime is coordinated to the metal ion through the nitrogen atom of the oxime. The only new feature in the IR spectra of the complexes is a strong and sharp absorption around $510 \mathrm{~cm}^{-1}$ which is assigned to the $v(\mathrm{Co}-\mathrm{N})$ vibration, these bands are not found in the spectrum of the ligand. These determinations are in good agreement with those described in the literature ${ }^{12-14}$.

The sharp and weak band occurring around $1020 \mathrm{~cm}^{-1}$ and $1145 \mathrm{~cm}^{-1}$ in all the complexes is assigned to the $\mathrm{N}-\mathrm{O}$ stretching vibration of the oxime moieties. All of the IR spectra of the 
Table I. Analytical Data of the Complexes ${ }^{2}$

\begin{tabular}{|c|c|c|c|c|c|c|c|c|}
\hline Compound Formula & F.Wt & Colour & $\begin{array}{l}\text { Yield } \\
(\%)\end{array}$ & $\mathrm{C}$ & $\begin{array}{c}\text { Anal. } \mathrm{F} \\
\mathrm{H}\end{array}$ & $\begin{array}{l}\text { ound (cal } \\
\mathrm{N}\end{array}$ & $\begin{array}{l}(\%) \\
\mathrm{Co}\end{array}$ & $X^{b}$ \\
\hline $\begin{array}{l}{\left[\mathrm{Co}(\mathrm{Hdmg})_{2}(\mathrm{Ala}) \mathrm{Cl}\right]} \\
\mathrm{CoC}_{11} \mathrm{H}_{21} \mathrm{~N}_{5} \mathrm{O}_{6} \mathrm{Cl}\end{array}$ & 413.5 & $\begin{array}{l}\text { Brown- } \\
\text { Greyish }\end{array}$ & 45 & $\begin{array}{l}30.6 \\
(31.0)\end{array}$ & $\begin{array}{c}4.7 \\
(5.0)\end{array}$ & $\begin{array}{l}16.5 \\
(16.9)\end{array}$ & $\begin{array}{l}14.3 \\
(14.2)\end{array}$ & $\begin{array}{c}8.2 \\
(8.6)\end{array}$ \\
\hline $\begin{array}{l}{\left[\mathrm{Co}(\mathrm{Hdmg})_{2}(\mathrm{Ala}) \mathrm{Br}\right]} \\
\mathrm{CoC}_{11} \mathrm{H}_{21} \mathrm{~N}_{5} \mathrm{O}_{6} \mathrm{Br}\end{array}$ & 453.5 & $\begin{array}{l}\text { Brown- } \\
\text { Green }\end{array}$ & 37 & $\begin{array}{l}28.3 \\
(28.8)\end{array}$ & $\begin{array}{l}4.7 \\
(4.6)\end{array}$ & $\begin{array}{l}15.8 \\
(15.3)\end{array}$ & $\begin{array}{l}13.0 \\
(12.9)\end{array}$ & $\begin{array}{c}16.9 \\
(17.4)\end{array}$ \\
\hline $\begin{array}{l}{\left[\mathrm{Co}(\mathrm{Hdmg})_{2}(\mathrm{Ala}) \mathrm{I}\right]} \\
\mathrm{CoC}_{11} \mathrm{H}_{21} \mathrm{~N}_{5} \mathrm{O}_{6} \mathrm{I}\end{array}$ & 505 & Brown & 45 & $\begin{array}{l}25.6 \\
(26.1)\end{array}$ & $\begin{array}{c}3.8 \\
(4.1)\end{array}$ & $\begin{array}{l}13.3 \\
(13.8)\end{array}$ & $\begin{array}{l}12.3 \\
(11.7)\end{array}$ & $\begin{array}{c}25.6 \\
(25.1)\end{array}$ \\
\hline $\begin{array}{l}{\left[\mathrm{Co}(\mathrm{Hdmg})_{2}(\mathrm{Ala}) \mathrm{SCN}\right]} \\
\mathrm{CoC}_{11} \mathrm{H}_{21} \mathrm{~N}_{5} \mathrm{O}_{6} \mathrm{~S}\end{array}$ & 436 & Brown & 69 & $\begin{array}{l}32.5 \\
(33.0)\end{array}$ & $\begin{array}{c}4.7 \\
(4.8)\end{array}$ & $\begin{array}{l}19.8 \\
(19.3)\end{array}$ & $\begin{array}{l}13.0 \\
(13.5)\end{array}$ & $\begin{array}{c}7.9 \\
(7.3)\end{array}$ \\
\hline $\begin{array}{l}{\left[\mathrm{Co}(\mathrm{Hdmg})_{2}(\mathrm{Thr}) \mathrm{Cl}\right] 2 \mathrm{H}_{2} \mathrm{O}} \\
\mathrm{CoC}_{12} \mathrm{H}_{27} \mathrm{~N}_{5} \mathrm{O}_{9} \mathrm{Cl}\end{array}$ & 479.5 & $\begin{array}{l}\text { Brown- } \\
\text { Greyish }\end{array}$ & 34 & $\begin{array}{l}29.8 \\
(30.0)\end{array}$ & $\begin{array}{c}5.5 \\
(5.8)\end{array}$ & $\begin{array}{c}15.1 \\
(14.6)\end{array}$ & $\begin{array}{c}12.0 \\
(12.3)\end{array}$ & $\begin{array}{c}7.4 \\
(7.4)\end{array}$ \\
\hline $\begin{array}{l}{\left[\mathrm{Co}(\mathrm{Hdmg})_{2}(\mathrm{Thr}) \mathrm{Br}\right]} \\
\mathrm{CoC}_{12} \mathrm{H}_{23} \mathrm{~N}_{5} \mathrm{O}_{7} \mathrm{Br}\end{array}$ & 488 & $\begin{array}{l}\text { Brown- } \\
\text { Greyish }\end{array}$ & 27 & $\begin{array}{l}29.0 \\
(29.5)\end{array}$ & $\begin{array}{c}4.7 \\
(4.7)\end{array}$ & $\begin{array}{l}14.1 \\
(14.3)\end{array}$ & $\begin{array}{c}12.3 \\
(12.1)\end{array}$ & $\begin{array}{c}16.9 \\
(16.4)\end{array}$ \\
\hline $\begin{array}{l}{\left[\mathrm{Co}(\mathrm{Hdmg})_{2}(\mathrm{Thr}) \mathrm{I}\right]} \\
\mathrm{CoC}_{12} \mathrm{H}_{23} \mathrm{~N}_{5} \mathrm{O}_{7} \mathrm{I}\end{array}$ & 535 & $\begin{array}{l}\text { Brown- } \\
\text { Dark }\end{array}$ & 35 & $\begin{array}{c}26.4 \\
(26.9)\end{array}$ & $\begin{array}{c}3.8 \\
(4.3)\end{array}$ & $\begin{array}{l}12.9 \\
(13.1)\end{array}$ & $\begin{array}{l}10.9 \\
(11.0)\end{array}$ & $\begin{array}{c}24.2 \\
(23.7)\end{array}$ \\
\hline $\begin{array}{l}{\left[\mathrm{Co}(\mathrm{Hdmg})_{2}(\mathrm{Thr}) \mathrm{SCN}\right]} \\
\mathrm{CoC}_{13} \mathrm{H}_{23} \mathrm{~N}_{6} \mathrm{O}_{7} \mathrm{~S}\end{array}$ & 446 & $\begin{array}{l}\text { Brown- } \\
\text { Red }\end{array}$ & 27 & $\begin{array}{c}32.9 \\
(33.4)\end{array}$ & $\begin{array}{c}4.5 \\
(4.9)\end{array}$ & $\begin{array}{l}18.6 \\
(18.1)\end{array}$ & $\begin{array}{c}13.2 \\
(12.7)\end{array}$ & $\begin{array}{c}7.1 \\
(6.9)\end{array}$ \\
\hline $\begin{array}{l}{\left[\mathrm{Co}(\mathrm{Hdmg})_{2}(\mathrm{His}) \mathrm{Cl}\right] 3 \mathrm{H}_{2} \mathrm{O}} \\
\mathrm{CoC}_{14} \mathrm{H}_{30} \mathrm{~N}_{7} \mathrm{O}_{9} \mathrm{Cl}\end{array}$ & 533.5 & Tan & 15 & $\begin{array}{c}31.2 \\
(31.5)\end{array}$ & $\begin{array}{l}5.6 \\
(5.6)\end{array}$ & $\begin{array}{c}17.9 \\
(18.4)\end{array}$ & $\begin{array}{l}10.8 \\
(11.0)\end{array}$ & $\begin{array}{c}7.0 \\
(6.6)\end{array}$ \\
\hline $\begin{array}{l}{\left[\mathrm{Co}(\mathrm{Hdmg})_{2}(\mathrm{His}) \mathrm{Br}\right] 8 \mathrm{H}_{2} \mathrm{O}} \\
\mathrm{CoC}_{14} \mathrm{H}_{3}{ }_{9} \mathrm{~N}_{7} \mathrm{O}_{14} \mathrm{Br}\end{array}$ & 668 & $\begin{array}{l}\text { Brown- } \\
\text { Rousse }\end{array}$ & 40 & $\begin{array}{c}25.1 \\
(25.2)\end{array}$ & $\begin{array}{c}5.2 \\
(5.3)\end{array}$ & $\begin{array}{l}14.7 \\
(14.7)\end{array}$ & $\begin{array}{l}8.5 \\
(8.6)\end{array}$ & $\begin{array}{c}11.8 \\
(12.0)\end{array}$ \\
\hline $\begin{array}{l}{\left[\mathrm{Co}(\mathrm{Hdmg})_{2}(\mathrm{His}) \mathrm{I}\right] 3 \mathrm{H}_{2} \mathrm{O}} \\
\mathrm{CoC}_{14} \mathrm{H}_{30} \mathrm{~N}_{7} \mathrm{O}_{9} \mathrm{l}\end{array}$ & 625 & $\begin{array}{l}\text { Brown- } \\
\text { Rousse }\end{array}$ & 34 & $\begin{array}{c}27.4 \\
(27.9)\end{array}$ & $\begin{array}{c}4.8 \\
(4.6)\end{array}$ & $\begin{array}{l}16.2 \\
(15.7)\end{array}$ & $\begin{array}{l}8.7 \\
(9.4)\end{array}$ & $\begin{array}{l}19.8 \\
(20.3)\end{array}$ \\
\hline $\begin{array}{l}{\left[\mathrm{Co}(\mathrm{Hdmg})_{2}(\mathrm{His}) \mathrm{SCN}\right] 3 \mathrm{H}_{2} \mathrm{C}} \\
\mathrm{CoC}_{15} \mathrm{H}_{30} \mathrm{~N}_{8} \mathrm{O}_{9} \mathrm{~S}\end{array}$ & 556 & $\begin{array}{l}\text { Brown- } \\
\text { Rousse }\end{array}$ & 19 & $\begin{array}{r}31.8 \\
(32.2)\end{array}$ & $\begin{array}{r}4.9 \\
(5.2)\end{array}$ & $\begin{array}{l}20.0 \\
(20.1)\end{array}$ & $\begin{array}{c}11.0 \\
(10.6)\end{array}$ & $\begin{array}{c}5.7 \\
(5.7)\end{array}$ \\
\hline
\end{tabular}

${ }^{\mathrm{a}}$ The complexes decompose and did not melt up to $300^{\circ} \mathrm{C}$

${ }^{\mathrm{b}} \mathrm{X}=\mathrm{Cl}, \mathrm{Br}, \mathrm{I}$ or $\mathrm{SCN}$. 


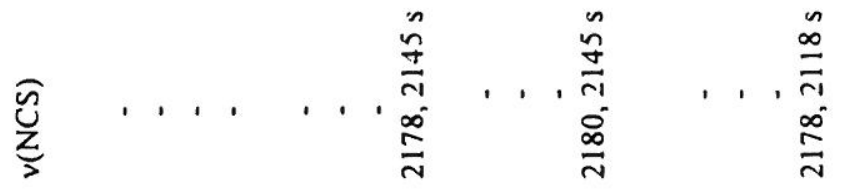

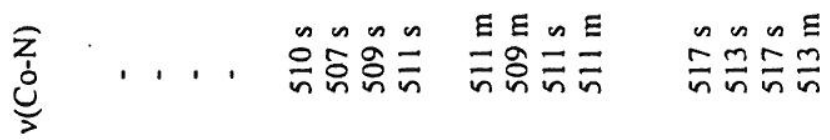

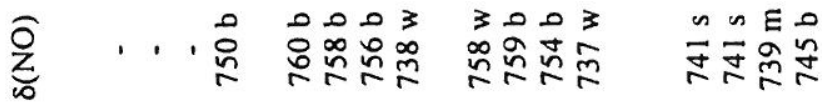

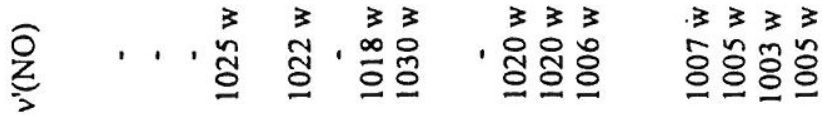

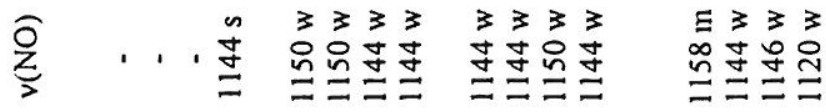

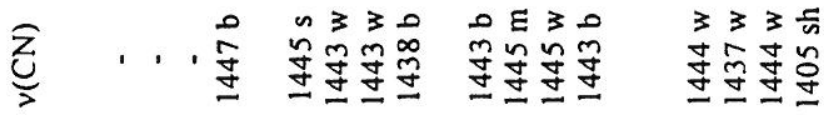

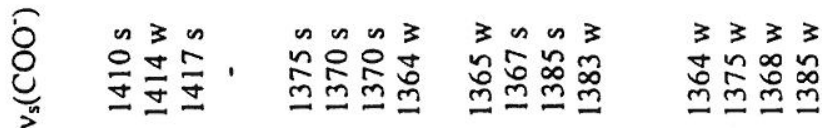

8.

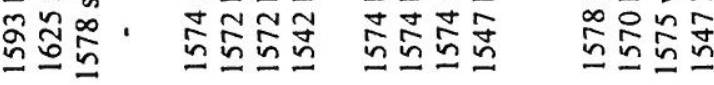

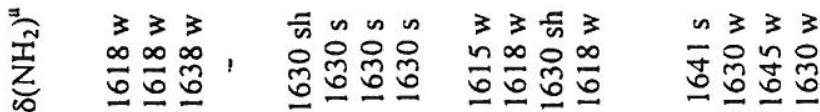

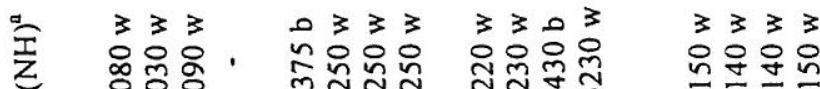

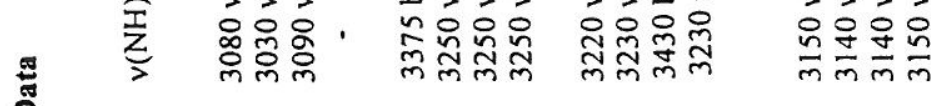


complexes exhibit a sharp band at $750 \mathrm{~cm}^{-1}$, attributed to the $\mathrm{C}=\mathrm{N}-\mathrm{OH}$ deformation vibration $^{12}$. In the three isothiocyanato complexes the very strong sharp bands at 2145 (Ala, Thr) and $2178 \mathrm{~cm}^{-1}$ (His) are due to $v(\mathrm{C}=\mathrm{N}$ ) vibrations of the coordinated isothiocyanato group"

\section{'H NMR Spectra}

The chemical shift of the dimethylglyoxime methyl resonance $(0.95 \mathrm{ppm})$ shifts considerably downfield in the complexes (around $2.50 \mathrm{ppm}$ ) indicating that this ligand is bound by the nitrogen atoms. The dimethylglyoximato methyl group resonances are almost invariant accross the series ${ }^{15}$ excepted for the thiocyanato complexes (2.23-2.40 ppm). The presence of one alanine or threonine ligand and two dimethylglyoximato ligands was confirmed by the $1: 4$ ratio of the corresponding methyl resonances. The signal at $10.4 \mathrm{ppm}$ in the spectra of the dimethylglyoxime attributed to the hydroxyl group is shifted downfield to $11.4 \mathrm{ppm}$ in the threonine and alanine complexes and is absent in the histidine complex spectra. This is probably due to the strong hydrogen bonding present in the histidine complex.

\section{Electronic Spectra}

In DMSO solutions (around $10^{-3} \mathrm{~mol} . \mathrm{L}^{-1}$ for Visible and $5.10^{-5} \mathrm{~mol} . \mathrm{L}^{-1}$ for UV spectra), the spectra of the complexes show two d-d transitions and one band due to ligand to metal charge transfer in the UV range. The position of these bands and the molar absorption coefficient $\varepsilon$ are given in Table III. The values are in good agreement with those already observed in pseudo octahedral cobalt(III) complexes ${ }^{16}$. The variation in the position of the transition bands allows us to obtain two spectrochemical series: $\mathrm{l}<\mathrm{Br}<\mathrm{Cl}<\mathrm{NCS}$ and $\mathrm{Thr}<\mathrm{His}<\mathrm{Ala}$ for the amino acids. In addition, we observe that the charge transfer bands are shifted to higher energies and this order follows the increasing electronegativities of the halogens.

Thus, on the basis of the analytical and spectroscopic data, all of the complexes of cobalt(III) have a pseudo-octahedral structure (see Fig. 1) where the two dimethylglyoxime monoanions are in the equatorial plane, and the monodendate ligands HA (amino acid) and X (halogen) occupy the two axial coordination sites.

\section{Thermal Analysis}

The TG and DTA curves show unambiguously that the loss of the crystallization water molecules occurs between 25 and $189^{\circ} \mathrm{C}$, particularly for the complexes containing histidine the temperature varies with the nature of the ligands. This process occurs mainly in one step but in two or even three steps in some cases. Stoichiometric calculations show that the weight 
Table III. Electronic Spectral Data of Cobalt(III) Complexes

\begin{tabular}{|c|c|c|c|}
\hline \multirow[t]{2}{*}{ Compound } & \multicolumn{3}{|c|}{ Electronic transitions ${ }^{a} \quad(\varepsilon)^{b}$} \\
\hline & ${ }^{1} A_{1 g} \rightarrow{ }^{1} T_{1 g}$ & ${ }^{1} A_{1 g} \rightarrow{ }^{1} T_{2 g}$ & $\pi \rightarrow e_{B}$ \\
\hline$\left[\mathrm{Co}(\mathrm{Hdmg})_{2}(\mathrm{Ala}) \mathrm{Cl}\right]$ & $17545(260)$ & - & $33670(720)$ \\
\hline$\left[\mathrm{Co}(\mathrm{Hdmg})_{2}(\mathrm{Ala}) \mathrm{Br}\right]$ & $17390(250)$ & $16660(275)$ & - \\
\hline$\left[\mathrm{Co}(\mathrm{Hdmg})_{2}(\mathrm{Ala}) \mathrm{I}\right]$ & $12285(560)$ & $22470(1900)$ & $25315(2300)$ \\
\hline$\left[\mathrm{Co}(\mathrm{Hdmg})_{2}(\mathrm{Ala}) \mathrm{SCN}\right]$ & $20620(1240)$ & $27030(4400)$ & - \\
\hline$\left[\mathrm{Co}(\mathrm{Hdmg})_{2}(\mathrm{Thr}) \mathrm{Cl}\right] 2 \mathrm{H}_{2} \mathrm{O}$ & $15150(60)$ & $18180(350)$ & $27390(1460)$ \\
\hline$\left[\mathrm{Co}(\mathrm{Hdmg})_{2}(\mathrm{Thr}) \mathrm{Br}\right]$ & $14490(110)$ & $17700(460)$ & $27030(1840)$ \\
\hline$\left[\mathrm{Co}(\mathrm{Hdmg})_{2}(\mathrm{Thr}) \mathrm{I}\right]$ & $10834(130)$ & $22370(1914)$ & $17390(1600)$ \\
\hline$\left[\mathrm{Co}(\mathrm{Hdmg})_{2}(\mathrm{Thr}) \mathrm{SCN}\right]$ & $20200(1066)$ & - & - \\
\hline$\left[\mathrm{Co}(\mathrm{Hdmg})_{2}(\mathrm{His}) \mathrm{Cl}\right] 3 \mathrm{H}_{2} \mathrm{O}$ & $17390(55)$ & $20200(112)$ & 27400 (1440) \\
\hline$\left[\mathrm{Co}(\mathrm{Hdmg})_{2}(\mathrm{His}) \mathrm{Br}\right] 8 \mathrm{H}_{2} \mathrm{O}$ & $15455(45)$ & $20200(312)$ & $26650(1300)$ \\
\hline$\left[\mathrm{Co}(\mathrm{Hdmg})_{2}(\mathrm{His}) \mathrm{I}\right] 3 \mathrm{H}_{2} \mathrm{O}$ & $13500(150)$ & $18700(484)$ & $24690(2440)$ \\
\hline$\left[\mathrm{Co}(\mathrm{Hdmg})_{2}(\mathrm{His}) \mathrm{SCN}_{3} \mathrm{H}_{2} \mathrm{O}\right.$ & $21050(1400)$ & $27050(220)$ & $33300(700)$ \\
\hline
\end{tabular}

'Wave number in $\mathrm{cm}^{-1}$

'Absorption molar coefficient in $\mathrm{mol}^{-1} \mathrm{~L} \mathrm{~cm}^{-1}$

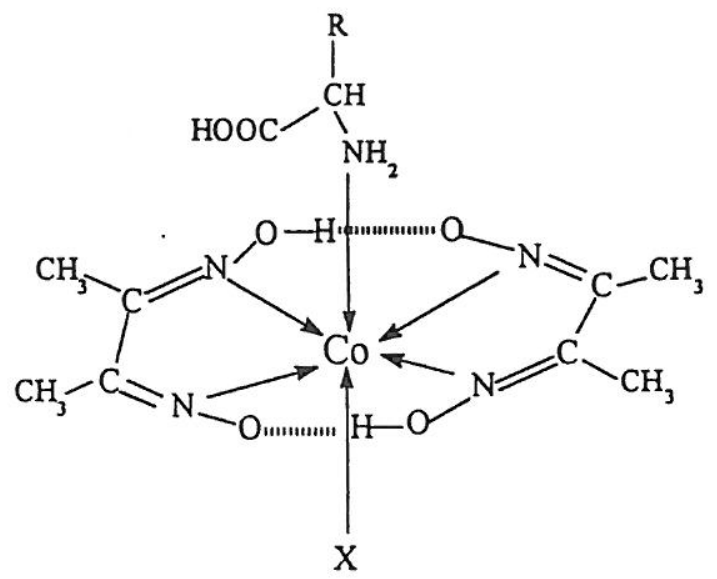

Fig. 1. Suggested Structure of the Complexes

$$
\mathrm{R}=\mathrm{CH}_{3}:(\mathrm{Ala}) ; \mathrm{R}=\mathrm{CH}_{3} \mathrm{CH}(\mathrm{OH}):(\mathrm{Thr}) ; \mathrm{R}=
$$


losses correspond approximately to the elimination of $\mathrm{HX}(\mathrm{X}=\mathrm{Cl}, \mathrm{Br}$, , or $\mathrm{SCN}$ ), $\mathrm{HA}$ ( $\mathrm{Ala}$, Thr or His) and $\mathrm{H}_{2} \mathrm{dmg}$.

Complexes [Co(Hdmg) $\left.b_{3}(\mathrm{Ala}) \mathrm{X}\right]$. In this series we note that $\mathrm{HCl}, \mathrm{HBr}$ and $\mathrm{HSCN}$ are eliminated between 125 and $210^{\circ} \mathrm{C}$ and, as it will be demonstrate below, a higher temperature is observed for $\mathrm{HI}$ compound. The elimination of $\mathrm{Ala}$ and $\mathrm{Thr}$ is faster than that of His and occurs at lower temperature. For the chloro complex, a simultaneous departure of Ala and $\mathrm{HCl}$ is observed. On one hand, we observed in the DTA curves, that the elimination of at least one molecule of dimethylglyoxime is characterized by an exothermic peak. On the other hand, we note that in the case of the iodo complex, the loss of $\mathrm{H}_{2} \mathrm{dmg}$ occurs at higher temperature via an endothermic process.

Complexes $\left[\mathrm{Co}\left(\mathrm{Hdmg} \mathrm{b}_{2}(\mathrm{Thr}) \mathrm{X}\right]\right.$. The observation of TG curves and the experimental data show that no molecules of water are involved here, exept for the chloro derivative. In this series the loss of $\mathrm{HCl}, \mathrm{HSCN}$ and $\mathrm{HBr}$ is observed at 91-136, 126-190 and 139-196 ${ }^{\circ} \mathrm{C}$, respectively, whereas for $\mathrm{HI}$ the range is $204-265^{\circ} \mathrm{C}$. In addition, we observed that in the bromo derivative the molecules of $\mathrm{HBr}$ and $\mathrm{Thr}$ are lost simultaneously. The pyrolysis of the whole series reveals a fast and important mass loss corresponding to the elimination of two molecules of $\mathrm{H}_{2} \mathrm{dmg}$.

Complexes [ $\mathrm{Co}(\mathrm{Hdmg})_{2}(\mathrm{His}) \mathrm{X}_{\mathrm{nn}} \mathrm{H}_{2} \mathrm{O}$. It is seen that $\left[\mathrm{Co}(\mathrm{Hdmg})_{2}(\mathrm{His}) \mathrm{Br}\right] 8 \mathrm{H}_{2} \mathrm{O}$ first loses crystallization water in three stages and the analogous $\mathrm{SCN}$ and $\mathrm{I}$ compounds in two steps. The DTA curves of the isothiocyanato and bromo complexes show that the elimination of $\mathrm{HSCN}$ and $\mathrm{HBr}$ occurs between $95-230^{\circ} \mathrm{C}$ and $189-244^{\circ} \mathrm{C}$, respectively. The loss of $\mathrm{HI}$ from the iodide complexes follows a more complicated pattern, the complete elimination of hydriodic acid needs higher temperature. The calculations show that this acid begins to decompose after the stepwise degradation of histidine which proceeds by successive breaking of the hydrocarbon chain. We may point out that the temperatures of elimination of HSCN, $\mathrm{HBr}$ and $\mathrm{HI}\left(95-230 ; 189-244\right.$ and $\left.250-422^{\circ} \mathrm{C}\right)$ are in the same order as the bonding strength as established by Varehlyi ${ }^{17}$ et al: $\mathrm{SCN}<\mathrm{Br}<1$.

The TG and DTA curves of the thiocyanato and bromo complexes show an important endothermic peak followed by a large weight loss between $400-500^{\circ} \mathrm{C}$. This phenomenon is due to the elimination of at least one $\mathrm{H}_{2} \mathrm{dmg}$ molecule. The pyrolysis of $\mathrm{H}_{2} \mathrm{dmg}$ occurs at higher temperature for the iodo compound. We observed that the pyrolysis of the thiocyanato and bromo complexes produces mainly endothermic reactions. For the iodo complexes both endothermic and exothermic steps are observed.

The study of the temperatures at which HX molecules are lost from the complexes indicates that in the three series the stability of these species increases in the order: $\mathrm{Ala}<\mathrm{Thr}<\mathrm{His}$. This 
Table IV. Thermal Decomposition Data of the Co(III) Complexes

\begin{tabular}{|c|c|c|c|c|c|}
\hline $\begin{array}{l}\text { Compound } \\
\text { (M.W.) }\end{array}$ & $\begin{array}{l}\text { Temperature } \\
\text { Range }\left({ }^{\circ} \mathrm{C}\right)\end{array}$ & $\begin{array}{l}\text { Weight } \\
\text { Obs }\end{array}$ & $\begin{array}{l}\text { Loss }(\%) \\
\text { Calc }\end{array}$ & Species formed & $\begin{array}{l}\text { DTA } \\
\text { peak }\end{array}$ \\
\hline $\begin{array}{l}{\left[\mathrm{Co}(\mathrm{Hdmg})_{2}(\mathrm{Ala}) \mathrm{Cl}\right]} \\
(413.5)\end{array}$ & $\begin{array}{l}106-149 \\
149-197 \\
197-306 \\
306-500\end{array}$ & $\begin{array}{l}8.70 \\
40.70 \\
53.00 \\
68.83\end{array}$ & $\begin{array}{l}8.60 \\
41.20 \\
52.40 \\
69.00\end{array}$ & $\begin{array}{l}\mathrm{Co}(\mathrm{Hdmg})_{2} \mathrm{Ala} \\
\mathrm{Co}(\mathrm{Hdmg})_{1.6} \\
\mathrm{Co}(\text { Hdmg })_{1.2} \\
\mathrm{Co}(\text { Hdmg })_{0.6}\end{array}$ & $\begin{array}{l}\text { End } \\
\text { Exo } \\
\text { Exo } \\
\text { Exo }\end{array}$ \\
\hline $\begin{array}{l}{\left[\mathrm{Co}(\mathrm{Hdmg})_{2}(\mathrm{Ala}) \mathrm{Br}\right]} \\
(458)\end{array}$ & $\begin{array}{l}123-168 \\
168-200 \\
200-285 \\
285-500\end{array}$ & $\begin{array}{l}17.50 \\
37.20 \\
56.60 \\
67.18\end{array}$ & $\begin{array}{l}17.46 \\
37.00 \\
56.90 \\
66.88\end{array}$ & $\begin{array}{l}\mathrm{Co}(\mathrm{Hdmg}) \mathrm{Ala} \\
\mathrm{Co}(\mathrm{Hdmg})_{2} \\
\mathrm{Co}(\mathrm{Hdmg})_{1.2} \\
\mathrm{Co}(\mathrm{Hdmg})_{0.85}\end{array}$ & $\begin{array}{l}\text { End } \\
\text { Exo } \\
\text { Exo } \\
\text { Exo }\end{array}$ \\
\hline $\begin{array}{l}{\left[\mathrm{Co}(\mathrm{Hdmg})_{2}(\mathrm{Ala}) \mathrm{l}\right]} \\
(505)\end{array}$ & $\begin{array}{l}120-149 \\
149-262 \\
262-444\end{array}$ & $\begin{array}{l}11.11 \\
33.93 \\
43.28\end{array}$ & $\begin{array}{l}11.10 \\
33.86 \\
42.80\end{array}$ & $\begin{array}{l}\mathrm{Co}(\mathrm{Hdmg})_{2} \text { Ala }{ }_{.51} \mathrm{I} \\
\mathrm{Co}(\mathrm{Hdmg})_{2} \mathrm{Ala}{ }_{0.51} \\
\mathrm{Co}(\mathrm{Hdmg})_{2}\end{array}$ & $\begin{array}{l}\text { Exo } \\
\text { End } \\
\text { End }\end{array}$ \\
\hline $\begin{array}{l}{\left[\mathrm{Co}(\mathrm{Hdmg})_{2}(\mathrm{Ala}) \mathrm{SCN}\right]} \\
(436)\end{array}$ & $\begin{array}{l}147-200 \\
200-222 \\
222-293 \\
293-550\end{array}$ & $\begin{array}{l}13.75 \\
24.00 \\
43.10 \\
67.60\end{array}$ & $\begin{array}{l}13.34 \\
23.60 \\
43.80 \\
68.10\end{array}$ & $\begin{array}{l}\mathrm{Co}(\mathrm{Hdmg})_{2} \mathrm{Ala} \mathrm{Al} \\
\mathrm{Co}(\mathrm{Hdmg})_{2} \mathrm{Ala}_{0.5} \\
\mathrm{Co}(\mathrm{Hdmg})_{1.6} \\
\mathrm{Co}(\mathrm{Hdmg})_{0.70}\end{array}$ & $\begin{array}{l}\text { End } \\
\text { Exo } \\
\text { Exo }\end{array}$ \\
\hline $\begin{array}{l}{\left[\mathrm{Co}(\mathrm{Hdmg})_{2}(\mathrm{Thr}) \mathrm{Cl}\right] 2 \mathrm{H}_{2} \mathrm{O}} \\
(479.5)\end{array}$ & $\begin{array}{l}91-136 \\
136-195 \\
195-276 \\
276-493 \\
493-550\end{array}$ & $\begin{array}{l}14.5 \\
24.36 \\
51.88 \\
63.18 \\
82.00\end{array}$ & $\begin{array}{l}14.90 \\
24.08 \\
52.20 \\
63.30 \\
81.40\end{array}$ & $\begin{array}{l}\mathrm{Co}(\text { Hdmg })_{2} \mathrm{Thr} \\
\mathrm{Co}(\mathrm{Hdmg})_{2} \mathrm{Thr}_{0.63} \\
\mathrm{Co}(\mathrm{Hdmg})_{1.48} \\
\mathrm{Co}(\mathrm{Hdmg}) \\
\mathrm{Co}(\text { Hdmg })_{0.26}\end{array}$ & $\begin{array}{l}\text { Exo } \\
\text { End } \\
\text { End } \\
\text { End } \\
\text { End }\end{array}$ \\
\hline $\begin{array}{l}{\left[\mathrm{Co}(\mathrm{Hdmg})_{2}(\mathrm{Thr}) \mathrm{Br}\right]} \\
(488)\end{array}$ & $\begin{array}{l}139-196 \\
196-292 \\
292-500\end{array}$ & $\begin{array}{l}52.68 \\
59.27 \\
71.49\end{array}$ & $\begin{array}{l}52.86 \\
58.88 \\
71.51\end{array}$ & $\begin{array}{l}\mathrm{Co}(\mathrm{Hdmg})_{1.5} \\
\mathrm{Co}(\mathrm{Hdmg})_{1.24} \\
\mathrm{Co}(\mathrm{Hdm})_{0.68}\end{array}$ & $\begin{array}{l}\text { Exo } \\
\text { Exo } \\
\text { Exo }\end{array}$ \\
\hline $\begin{array}{l}{\left[\mathrm{Co}(\mathrm{Hdmg})_{2}(\mathrm{Thr}) \mathrm{l}\right]} \\
(535)\end{array}$ & $\begin{array}{l}24-185 \\
185-204 \\
204-265 \\
265-455\end{array}$ & $\begin{array}{l}6.30 \\
11.39 \\
51.69 \\
73.80\end{array}$ & $\begin{array}{l}6.35 \\
11.58 \\
52.52 \\
74.00\end{array}$ & $\begin{array}{l}\mathrm{Co}(\text { Hdmg })_{2} \mathrm{Thr}_{0.71} \mathrm{I} \\
\mathrm{Co}(\text { Hdmg })_{2} \mathrm{Thr}_{0.48 \mathrm{I}} \\
\mathrm{Co}(\mathrm{Hdmg})_{1.70} \\
\mathrm{Co}(\mathrm{Hdmg})_{0.70}\end{array}$ & $\begin{array}{l}\text { End } \\
\text { Exo } \\
\text { Exo } \\
\text { End }\end{array}$ \\
\hline $\begin{array}{l}{\left[\mathrm{Co}(\mathrm{Hdmg})_{2}(\mathrm{Thr}) \mathrm{SCN}\right]} \\
(466)\end{array}$ & $\begin{array}{l}126-190 \\
190-230 \\
230-500\end{array}$ & $\begin{array}{l}12.62 \\
59.57 \\
72.34\end{array}$ & $\begin{array}{l}12.44 \\
59.23 \\
71.50\end{array}$ & $\begin{array}{l}\mathrm{Co}(\mathrm{Hdmg})_{2} \mathrm{Thr} \\
\mathrm{Co}(\text { Hdmg })_{1 .+} \\
\mathrm{Co}(\text { Hdmg })_{0.36}\end{array}$ & $\begin{array}{l}\text { End } \\
\text { Exo } \\
\text { Exo }\end{array}$ \\
\hline $\begin{array}{l}{\left[\mathrm{Co}(\mathrm{Hdmg})_{2}(\mathrm{His}) \mathrm{Br}\right] 8 \mathrm{H}_{2} \mathrm{O}} \\
(668)\end{array}$ & $\begin{array}{l}25-92 \\
92-110 \\
189-244 \\
244-397 \\
397-550\end{array}$ & $\begin{array}{l}5.40 \\
13.33 \\
40.40 \\
57.08 \\
78.87\end{array}$ & $\begin{array}{l}5.39 \\
13.47 \\
40.56 \\
56.90 \\
78.74\end{array}$ & $\begin{array}{l}{\left[\mathrm{Co}(\mathrm{Hdmg})_{2} \mathrm{HisBr}\right] 6 \mathrm{H}_{2} \mathrm{O}} \\
{\left[\mathrm{Co}(\mathrm{Hdmg})_{2} \mathrm{His} \mathrm{Br}\right] 3 \mathrm{H}_{2} \mathrm{O}} \\
\mathrm{Co}(\mathrm{Hdmg})_{2} \mathrm{His}_{0.70} \\
\mathrm{Co}(\mathrm{Hdmg})_{2} \\
\mathrm{Co}(\mathrm{Hdmg})_{0.73}\end{array}$ & $\begin{array}{l}\text { End } \\
\text { End } \\
\text { End } \\
\text { End } \\
\text { End }\end{array}$ \\
\hline $\begin{array}{l}{\left[\mathrm{Co}(\mathrm{Hdmg})_{2}(\mathrm{His})[] 3 \mathrm{H}_{2} \mathrm{O}\right.} \\
(625)\end{array}$ & $\begin{array}{l}26-54 \\
54-90 \\
90-159 \\
159-250 \\
250-422 \\
422-480\end{array}$ & $\begin{array}{l}5.30 \\
11.43 \\
21.22 \\
27.80 \\
40.00 \\
53.06\end{array}$ & $\begin{array}{l}5.76 \\
10.06 \\
20.96 \\
28.00 \\
40.32 \\
53.90\end{array}$ & $\begin{array}{l}{\left[\mathrm{Co}(\mathrm{Hdmg})_{2} \mathrm{His} \mathrm{I}^{\mathrm{I}}\right] 1.5 \mathrm{H}_{2} \mathrm{O}} \\
\mathrm{Co}(\mathrm{Hdmg})_{2} \mathrm{His} \mathrm{I} \\
\mathrm{Co}(\mathrm{Hdmg})_{2} \mathrm{His}_{0 . .56} \mathrm{I} \\
\mathrm{Co}(\mathrm{Hdmg})_{2} \mathrm{His}_{0.28} \mathrm{I} \\
\mathrm{Co}(\mathrm{Hdmg})_{2} \mathrm{His}_{0.19} \mathrm{I}_{0.5} \\
\mathrm{Co}(\mathrm{Hdmg})_{2} \mathrm{His}_{0.11}\end{array}$ & $\begin{array}{l}\text { Exo } \\
\text { Exo } \\
\text { Exo } \\
\text { Exo } \\
\text { End } \\
\text { End }\end{array}$ \\
\hline $\begin{array}{l}{\left[\mathrm{Co}(\mathrm{Hdmg})_{2}(\mathrm{His}) \mathrm{SCN}\right] 3 \mathrm{H}_{2} \mathrm{O}} \\
(556)\end{array}$ & $\begin{array}{l}25-95 \\
95-230 \\
230-294 \\
294-460 \\
460-550\end{array}$ & $\begin{array}{l}6.20 \\
31.00 \\
41.00 \\
61.15 \\
78.50\end{array}$ & $\begin{array}{l}647 \\
31.00 \\
42.60 \\
61.50 \\
79.10\end{array}$ & $\begin{array}{l}{\left[\mathrm{Co}(\mathrm{Hdmg})_{2} \mathrm{HisSCN}_{3} \mathrm{H}_{2} \mathrm{O}\right.} \\
\mathrm{Co}(\mathrm{Hdmg})_{2} \mathrm{His}_{0.52} \\
\mathrm{Co}(\mathrm{Hdmg})_{2} \mathrm{His}_{0.19} \\
\mathrm{Co}(\mathrm{Hdmg})_{1.39} \\
\mathrm{Co}(\mathrm{Hdmg})_{0.5}\end{array}$ & $\begin{array}{l}\text { Exo } \\
\text { End } \\
\text { End } \\
\text { End } \\
\text { End }\end{array}$ \\
\hline
\end{tabular}


order may be explained by the presence of stronger hydrogen bonding with Thr and His, because of the presence of $\mathrm{OH}$ (Thr) and nitrogen atoms (His).

Considering a series containing the same amino acid, thermal analyses show that in all cases the strengths of the $\mathrm{Co}(\mathrm{III})-\mathrm{X}$ bond is greater with iodide than with $\mathrm{Cl}, \mathrm{Br}$ and $\mathrm{SCN}$; for these three ions the order varies with the nature of the amino acid.

The stoichiometric calculation of the weight loss indicates that the pyrolysis of His and Thr proceeds by successive degradation while Ala mainly decomposes in one step. In the three series, the elimination of two molecules of dimethylglyoxime occurs after the elimination of $\mathrm{HX}(\mathrm{X}=\mathrm{Cl}, \mathrm{Br}$ or $\mathrm{SCN})$ and the amino acid. When $\mathrm{X}=\mathrm{I}$, we note that around $500-550^{\circ} \mathrm{C}$, only one molecule of $\mathrm{H}_{2} \mathrm{dmg}$ is eliminated.

\section{REFERENCES}

1. D. G. Brown, Prog. Inorg. Chem., 18, 177 (1973).

2. M. Hoshino, S. Konishi, Y. Teral and M. Imamura, Inorg. Chem., 21, 89 (1982).

3. P. J. Toscano and L. G. Marzilli, Prog. Inorg . Chem., 31, 105 (1984).

4. J. Halpern, Science, 227, 869 (1985).

5. J. M. Pratt, Chem. Soc. Rev., 14, 161 (1985).

6. M. Megnamizi-Belombé and H. Endres. Z. Naturforsch., B 42, 1 (1987).

7. M. Megnamisi-Belombé and B. Nuber, Z. Naturforsch., B $\underline{45}, 1508$ (1990).

8. X. Solans, M. Font-Bardia, C. Lopez and S. Alvarez, Acta Cryst., Cㅌ2, 63 (1996)

9. N. J. Geary, Coord. Chem. Rev., 7, 81 (1971).

10. L. J. Bellamy "The Infrared Spectra of Complexes Molecules", 3rd Edn. Wiley, New York, p. 226 (1975).

11. K. Nakamoto "Infrared and and Raman Spectra of Inorganic and Coordination Compounds", 3rd Edn., Wiley, New York, p. 273 (1972).

12. V. K. Saxena, M. Gupta and M. N. Srivastava, Synth. React. Inorg. Met.-Org. Chem. 26 1661 (1996).

13. M. Mohapatra and V. Chakravorty, Polyhedron, $\underline{8}, 1509$ (1989).

14. V. Alexander, Inorg. Chim., Acta, 204. 109 (1993).

15. D. C. Ware, D. S. Mackie, P. J. Brothers and W. A. Denny, Polyhedron 12, 1371 (1993).

16. A. B. P. Lever, "Inorganic Electronic Spectroscopy", 2nd Edn., Elsevier, Amsterdam, p. 473 (1984).

17. C. Varhelyi and J. Zsako, J. Thermal Anal., 32, 785 (1987).

Received: 1 October 1999

Accepted: 22 July 2000
Referee I: G. Brewer

Referee II: D. J. R. Brook 